\title{
БЪЛГАРСКАТА ПРАВОСЛАВНА ЦЪРКВА И КУЛТУРНОТО РАЗВИТИЕ НА БЬЛГАРИЯ В ПЕРИОДА МЕЖДУ ДВЕТЕ СВЕТОВНИ ВОЙНИ
}

\author{
Св. Елдъров
}

\begin{abstract}
Елдаров Св. Болгарська православна церква та культурний розвиток Болгарії у період між двома світовими війнами. Як привілейована, згідно з конституцією, конфесія, Болгарська православна церква (БПЦ) відіграє важливу роль у житті болгарського суспільства. У період між двома світовими війнами вона намагається вплинути й на культурний розвиток країни. Політику та діяльність БПЦ у сфері культури формує і спрямовує Культурно-просвітницьке відділення при Святому Синоді. За його допомоги верховне управління церкви досягає значних успіхів у книгодрукуванні та розповсюдженні книг. Важливу роль в її культурній діяльності відіграє церковно-релігійна періодика на чолі з синодальним офіціозом «Церковна газета» («Цьрковен вестник»). У статті розглянуті також спроби БПЦ пробудити інтерес до релігійної тематики у середовищі художньої інтелігенції, використати для свого культурного місіонерства радіо та кіно, розширити рамки свого впливу в сферах освіти та виховання молоді, проникнути за допомогою різного роду релігійно-громадських організацій до всіх соціальних верств болгарського суспільства.
\end{abstract}

Ключові слова: Болгарська православна церква; культура; засоби масової інформації; освіта; виховання.

Элдыров Св. Болгарская православная церковь и культурное развитие Болгарии в период между двумя мировыми войнами. Как привилегированная, согласно конституции, конфессия, Болгарская православная церковь (БПЦ) играет важную роль в жизни болгарского общества. В период между двумя мировыми войнами она пытается оказать влияние и на культурное развитие страны. Политику и деятельность БПЦ в сфере культуры формирует и направляет Культурно-просветительское отделение при Святом Синоде. С его помощью верховное управление церкви достигает значимых успехов в книгопечатании и распространении книг. Важную роль в ее культурной деятельности играет церковно-религиозная периодическая печать во главе с синодальным официозом «Церковная газета» («Цьрковен вестник»). В статье рассмотрены также попытки БПЦ пробудить интерес к религиозной тематике в среде художественной интеллигенции, использовать для своего культурного миссионерства радио и кино, расширить рамки своего влияния в сферах образования и воспитания молодежи, проникнуть с помощью разного типа религиозно-общественных организаций во все социальные слои болгарского общества.

Ключевые слова: Болгарская православная церковь; культура; средства массовой информации; образование; воспитание.

Eldarov Sv. Bulgarian Orthodox Church and the cultural development of Bulgaria during the period between the two World Wars. As an institution of the national religion legitimized by Constitution, the Bulgarian Orthodox Church (BOC) plays an important role in the life of the Bulgarian public. During the period between the two World Wars, it also attempted to influence the cultural development of the country. The cultural policy and activity of the BOC were formed and directed by the Department of Culture and Education at the Holy Synod. Through it, the Supreme Church council achieved material success in book publishing and dissemination. Ecclesiastical and religious press, headed by the official issue of the Synod, "Church Newspaper" ("Tsarkoven Vestnik"), played an important role in the cultural activity. Furthermore, this paper focuses on the attempts of the BOC to provoke the artistic creation circles' interest to the religious subject matter, to use radio and cinema for the purposes of its cultural missionary activity, to expand its influence in the field of youth education and cultivation, to use various religious and social organizations as a means for accessing all social layers of the Bulgarian society.

Keywords: Bulgarian Orthodox Church; culture; media; education; cultivation.

След три изтощителни войни и две национални катастрофи проблемът за мястото и ролята на Българската православна църква (БПЦ) в държавата и обществото, а в частност за нейната мисия в културните потребности на страната, добива изключителна актуалност и острота. Първата реакция на върховната църковна управа е да направи опит да се разграничи от отговорността за националните катастрофи. Със специално послание, разпространено в хиляди екземпляри и публикувано в „Църковен вестник“, Св. Синод призовава българския народ към „особен покайно-молитвен подвиг“, като определя датата 5 януари 1919 г. за ден на строг пост и усърдни молитви във всички храмове на страната. 
Синодалното послание търси причините за провала на България в „душата и сърцата на българите“, т.е. в недъзите на духовния живот на българското общество

Стремежът на БПЦ да се дистанцира от политическите събития всъщност е опит да се разграничи от самата себе си, тъй като българите, пък и чужденците, едва ли са забравили нейните повици за „благоразумно политическо безмълвие“ и химните ѝ в прослава на войната и официалната германофилска политика в периода 1915-1918 г. Това е и опит да се отклони в друга посока недоволството в църковните среди от политическия курс и вътрешното състояние на БПЦ. Решителният сблъськ между старото и новото се разиграва в навечерието и по време на Църковно-народния събор през 1921-1922 г. Веднага след установяването на мира гласовете за реформи и преобразования в цьрковната администрация и дейност, които впрочем звучат приглушено още в предвоенния период, започват да се надигат с нова сила. Този път върховната църковна управа не е в състояние да ги заглуши и игнорира, най-малкото защото в тях сега се вслушва и земеделското правителство на Александър Стамболийски. Още повече, че в очите на всички - и църковници, и държавници, и граждани - исканията за промени са напълно основателни и легитимни.

Върховната църковна управа сама разбира това, но иска да държи процесите под абсолютен и неоспорим контрол. Това желание обаче никак не съответства на възможностите ѝ към момента. Вътрешно-църковната опозиция се обръща за подкрепа към Стамболийски, който на 16 април 1920 г. освен премиерския пост поема и управлението на Министерството на външните работи и изповеданията (МВРИ). Земеделският лидер, обладан от силата на своята партия и от амбицията на новото политическо поколение, не оставя нито за миг да му се изплъзне кормилото на църковната обнова.

Църковно-народният събор се открива на 6 февруари 1921 г. и заседава с прекъсвания до 16 февруари 1922 г. в сградата на Народното събрание. На другия ден след откриването Стамболийски държи реч пред съборните делегати, която трасира пътя на църковното обновление в следвоенния период. Неговата визия за ролята на църквата в модерния свят ѝ отрежда мястото на своего рода „лечебен институт“, който да предпазва и лекува българската нация от социални пороци, чужди влияния и идейна безпьтица, да води борба против моралния и физическия упадък на народа, да вдъхва надежда и оптимизъм у личността, семейството и обществото. Сред приоритетите на БПЦ той поставя религиозното възпитание на обществото и най-вече на младежта, активизиране на църковната проповед чрез устното и печатното слово и довеждането ѝ до съзнанието на обикновените хора, борба с алкохолизма и другите вредители на народното здраве, противопоставяне на безбожническите идеи, на комунистическата пропаганда и др. ${ }^{2}$

Много скоро не друг, а самата върховна църковна управа ще прозре, че в същността на идеите си Стамболийски е бил прав. Неговият повик към църквата да се превърне в „лечебен институт“ на обществото не само не противоречи, но представлява основна цел и задача на църковната мисия. Самата действителност изважда наяве болестното състояние на българския обществен организъм и диктува на БПЦ да влезе в препоръчваната от бившия министър-председател изцелителна роля. Поводът наистина е ужасен - атентатьт в катедралния храм „Св. Неделя“ в столицата на България на 16 април 1925 г., който отнема десетки невинни живота и компрометира пред цивилизования свят цял един народ. Два дена преди него е извършен неуспешен опит за атентат срещу цар Борис III в Арабаконашкия проход. Двете злодеяния, дело на българските комунисти, съвпадат със Страстната седмица на Великденските празници и изтръгват вълна от възмущение в българското общество. Сега особено високо и силно прозвучава и гласът на БПЦ.

В извънредно заседание на 27 април 1925 г. Св. Синод съставя и приема едно „Послание до православния български народ“. Върховната църковна управа окачествява двата атентата като „сатанинско покушение“ срещу държавата и народа. Чрез тях злодейците искат да погребат България, като убият царя и министрите, а атентатът в „Св. Неделя“ няма аналог в историята на човечеството: „В такъв именно свят и неприкосновен дом за молитва, и в един от най-светите църковни дни, осатанените от злоба вероотстъпници и човекомразци с жестока подлост избиха стотици невинни души, и то през време на богослужение“ - възмущават се синодалните архиереи. Те обаче изрично подчертават, че не е достатъчно само човек да се ужаси от грозното престьпление и да го заклейми, но да разбере къде са корените на злото. И синодалното послание му ги посочва - те са в тъмния и мрачен път, в който българският народ върви от десетки години, като насажда у себе си 
култура без Бог, просвета без религия и общество без църква. Чрез посланието си Св. Синод призовава народните водачи да отхвърлят образованието без религия, свещениците да проповядват мир, любов и братолюбие, а учителите да пръскат семето на чистата наука и да възпитават децата в твърдите религиозни принципи ${ }^{3}$. Така културното мисионерство, разбирано като един вид реевангелизация на българския народ, се преврьща в приоритет за БПЦ.

За да може да насочва и контролира разнородните тенденции в културната сфера, както и да рационализира и усъвършенства цялостната си работа, през 1925 г. Св. Синод се решава на важна административна реформа. В заседанието си на 9 април върховната църковна управа приема „Правилник за службите и вътрешния ред в канцеларията на Синода“, който поставя синодалната администрация на нови начала. Начело на синодалната канцелария стои секретар, който централизира в своята длъжност ръководството и надзора на нейните отделения, дирекции и служби. Той проучва и докладва всички въпроси, свързани с изграждането, поддържането и функционирането на църковната администрация и преди всичко изборите на синодални членове и епархийски архиереи, епархийски духовни и мирски съвети и избиратели, църковни настоятелства. Секретарят следи и докладва по всички въпроси за отношенията между църквата и държавата, води протоколите на синодалните заседания и делата от конфиденциален характер на всички канцеларски служби, заверява с подписа си по-важните писма на наместник-председателя, подписва от негово име маловажните документи, отговаря за входящата и изходящата регистратура, протоколите и архивата. Може да се каже, че синодалният секретар е натоварен с голяма власт и отговорност, което го превръща в ключова фигура във върховната църковна управа и в БПЦ въобще. Тогава тази длъжност се изпълнява от протопрезвитер професор д-р Стефан Цанков, една от най-влиятелните фигури в църквата, а в навечерието на Втората световна война - и ректор на Софийския университет.

С оглед на културното мисионерство на БПЦ нова тежест и функции придобива Културно-просветното отделение при синодалната канцелария. Освен грижата за просветната, социално-благотворителната и стопанската дейност на върховната църковна управа, върху него ляга отговорността да защитава учението на православната църква, което означава, че трябва да следи и проучва всички инославни, сектантски и противодържавни движения и пропаганди и да препоръчва мерки за тяхното ограничаване. В неговите компетенции спадат също въпросите за правилното и точно изпълнение на богослужението, за изграждането на нови църкви и параклиси, за поддържането и развитието на ставропигиалните манастири, за рькополагането на свещеници, за присъждането на офикии. Едни от найважните задачи на отделението, които оправдават наименованието и същността му като институция, произтичат от грижите за издаването на богослужебни книги, за преглеждане и одобряване на учебниците по Закон Божи и църковно-богословските дисциплини, за дейността на духовните училища, православните и свещеническите братства, за общия надзор върху морала на православната общност. Всички тези отговорности падат върху служителите на отделението, чийто началник е архимандирт Стефан Абаджиев.

В тясна връзка с Културно-просветното отделение (КПО) се намират и функционират още две служби на синодалната канцелария. Дирекцията за църковно книгоиздателство и разпространяване на духовна книжнина организира в техническо отношение цьрковния печат и се грижи за неговото разпространение, изучава противорелигиозната и антицьрковната литература и ѝ противодейства с развитието на православна книжнина, надзирава църковните книгопродавци, отговаря за автентичността на църковната музика. Редакцията и администрацията на „Цьрковен вестник“ се грижат за списването, издаването и разпространението на синодалния орган, а също и за правилния вървеж на свързаните с него притурки и издания ${ }^{4}$.

Реформирането на синодалната канцелария оказва благотворно въздействие върху развитието на културната дейност на БПЦ. Централно място в нея заема издаването и разпространението на църковно-религиозна книжнина. Новото начало е поставено още в заседанието на Св. Синод на 4 октомври 1921 г. с единодушно решение да се достави от чужбина оборудване за печатница - предварително именована „Синодална типография“ - която да печата църковно-богослужебни книги, учебници, богословска литература, периодика и въобще цялата печатна продукция на църквата. Охридският митрополит Борис е натоварен да проучи германския пазар. Точно след един месец Св. Синод се обръща към 
МВРИ с молба да получи разрешение да внесе от чужбина печатната машина, като определя и комисия за нейното закупуване и доставка 5 .

Първоначално изглежда, че и това начинание ще заглъхне от само себе си или ще бъде провалено умишлено, както става с други амбициозни предприятия на БПЦ. И наистина, докато на власт е правителството на БЗНС, по този въпрос не се прави почти нищо. Само веднъж през тези години във върховната църковна управа пак става дума за нея, когато през лятото на 1922 г. секретарят С. Цанков внася за разглеждане проект за учредяване на синодална печатница под формата на кооперация. Той дори избира подходящо име - „Светлина“. Като премислят обаче всички плюсове и минуси, синодалните архиереи стигат до заключението, че проектът е „неприемлив от гледище на сигурните интереси на Св. Синод и църквата“. За по-задълбочено и компетентно изучаване на този въпрос е съставена комисия с председател С. Цанков. Тя получава мандат да проучи и офертата на Придворната печатница, която предлага да предостави част от своя инвентар за нуждите на БПЦ срещу парична гаранция от един милион лева ${ }^{6}$.

След като кризата във взаимоотношенията със земеделския режим отшумява, върховната църковна управа най-сетне прави първата решителна стъпка за осъществяването на своята стара идея. В заседанието си на 23 юли 1924 г. тя решава да основе нова служба под името „Дирекция на църковното книгоиздателство и разпространяване на духовна книжнина“. За неин пръв директор е назначен архимандрит Стефан Абаджиев, дотогава началник на КПО. Старата му длъжност е поверена на архимандрит Борис, протосингел на Софийската митрополия и бъдещ Неврокопски митрополит. Новата дирекция трябва да започне да функционира от 1 ноември с. г. ${ }^{7}$

На 17 септември С. Абаджиев внася за обсъждане в Св. Синод „Временни правила за Дирекцията на църковното книгоиздателство“, с което начертава амбициозна програма на подведомствената си служба. Първата стъпка е обстойна инвентаризация на синодалния книжен склад, каквато от години не е правена. Целта е залежалата стока да стигне до евентуалните си читатели, макар и на намалена цена. Очаква се също ревизията на преписките по изпращането на печатни материали до митрополиите, епархийските наместничества и други адресати да позволи събирането на неизплатените от тях суми. Най-важно значение за разпространението на църковно-религиозната книжнина обаче има предложението на С. Абаджиев за създаване на институцията „синодални книгопродавци“. В неговата визия това са „православни и ревностни християни“, които ще разпространяват синодалните издания по градове и села. Те ще се смятат за синодални чиновници под ведомството на дирекцията, но вместо заплата ще получават $60 \%$ от продажната цена на пласираните книги. Проектът на С. Абаджиев съдържа и други практически и целесъобразни предложения, като разкриване на книжарници към църковните свещоливници, ясни правила при ценообразуването на духовната литература и пр. ${ }^{8}$

Само за два месеца амбициозният ръководител на синодалното книгоиздаване и книгоразпространение успява да осъществи част от своите идеи. Освен че въвежда ред в книжния склад, той успява да издейства назначаването на трима разпространители, както и издаването на малки брошури с популярно църковно-религиозно съдържание 9 . Преди да е изтекла годината, С. Абаджиев успява да върне в дневния ред на Св. Синод и въпроса за печатницата. Сформирана е нова комисия под негово председателство, която да доведе начинанието до край ${ }^{10}$.

Енергичните стьпки на директора на Църковното книгоиздателство дават резултат. През 1926 г. той представя на вниманието на Св. Синод мащабна програма за културнопросветна дейност със силата на устното и печатното слово. Централно място в нея заема идеята за издаване и разпространение на религиозни брошури. Тази наглед обикновена дейност С. Абаджиев структурира в няколко равнища на изпълнение, които напомнят модерния принцип на пазарния маркетинг. Като за начало той препоръчва да се съберат подробни сведения за противорелигиозната, антицърковната и сектантската пропаганда в епархиите. Въз основа на събраната, анализирана и систематизирана информация се определят въпросите, по които ще се издават брошури или ще се изнасят сказки. След това се канят богослови или други квалифицирани лица, които да развият зададените теми. Текстовете се преглеждат от специална комисия при Дирекцията на църковното книгоиздателство. По тази система годишно могат да бъдат отпечатвани 24 брошури с общ обем 40-50 коли и с тираж до 10 хиляди екземпляра. Чрез Съюза на българските читалища и 
Министерството на народната просвета (МНП) брошурите ще бъдат изпращани безплатно на всички читалища, прогимназии и гимназии в страната ${ }^{11}$.

Директорът на синодалното книгоиздателство дава и редица други препоръки, сред които се откроява идеята за създаването на редакционен комитет, упълномощен да избира актуалните теми и въпроси, да дава упътвания и насоки на лекторите и авторите, да се грижи за печатането и разпространението на изданията. Той се състои от секретаря на Св. Синод, началника на КПО и директора на Църковното книгоиздателство.

През 20-те години на XX в. БПЦ постига немалки успехи в книгоиздателската дейност. Най-забележителният от църковно-религиозна гледна точка безспорно е издаването на пълния текст на Библията на новобългарски език. Това мащабно начинание, по което Св. Синод мисли и работи още от края на XIX в., е завършено през 1925 г. Библията е отпечатана в Държавната печатница в 50 хиляди екземпляра, като заедно с нея са отпечатани като самостоятелни книжни тела и нейните части (Новия завет, притчите, псалмите и пр.) в тираж от 5 до 20 хиляди екземпляра. Ст. Цанков оценява това като „един голям факт и едно знаменито начало в историята на църковната дейност за духовна просвета в наше време“. През същия период са отпечатани 42 учебника, пособия и други книги в общ тираж от близо 120 хиляди екземпляра, 78 брошури в над 520 хиляди екземпляра. Заедно с учебниците, книгите и брошурите Св. Синод поръчва и доставя - главно от чужбина заради по-доброто качество - огромно количество икони, книжни щампи, албумчета и картички с религиозно съдържание ${ }^{12}$.

По-голямата част от изданията на Св. Синод се печатат в печатницата на Ставропигиалното женско монашеско братство „Бял кръст“. То е основано през 1922 г. от архим. С. Абаджиев с цел да „развива делото на християнското милосьрдие и нравствено-религиозно възпитание“ чрез училища, пансиони, забавачници, детски колонии, приюти, болници и пр. В края на 20-те обаче братството изпада в тежка организационна и кадрова криза, не на последно място, и по вина на своя основател и ръководител ${ }^{13}$. Без съмнение той е много активен в генерирането на мащабни идеи, но иначе не е твърде последователен в тяхното осъществяване. Този стил на управление С. Абаджиев проявява и в битността си на директор на синодалното книгоиздаване и книгоразпространение. В крайна сметка това му струва дльжността.

Слабата страна в дейността на С. Абаджиев е разпространението на печатните издания. Голяма част от книжната продукция залежава в синодалния склад и не достига до потенциалните читатели. Такава е съдбата на близо една трета от тиража на Библията и нейните части, на половината от учебниците, на две трети от брошурите и на преобладаващата част от богослужебните книги. Общо през 1927 г. стойността на залежалите в хранилището книги надхвърля 13 млн. лв., докато приходите от реализираната продукция възлизат на около 9 млн. лв. ${ }^{14}$

В следващите години БПЦ полага по-големи усилия за разпространението и популяризирането на своята печатна продукция. Известна роля за облекчаването на синодалния склад изиграва институтът на църковните книгоразпространители. В същата насока действа и върховната църковна управа. През 1929 г. Св. Синод се обръща с молба към МНП да препоръча със специално окръжно Библията на всички училищни и читалищни библиотеки. По-късно БПЦ получава и правото да има свои представители в настоятелствата и комисиите, които се грижат за попълването на библиотечните фондове. По този начин църквата се стреми не само да пласира своята продукция, но и да предпази читателите от някои - по нейно мнение - „кощунствени книги“, като например романа „Между пустинята и живота“" на Николай Райнов ${ }^{15}$.

Кризата в църковното книгоиздаване и книгоразпространение е преодоляна частично през 1932 г., когато след уволнението на архим. Ст. Абаджиев, с тази дейност се заема лично синодалният секретар, Стобийският епископ Борис. Той начертава нова програма, която залага на издаването и разпространяването на брошурна книжнина, съобразена с възможностите и интересите на различните социални прослойки. За интелигенцията и учащата се младеж епископ Борис препорьчва поредица от брошури, които в популярна форма да развиват различни религиозни въпроси, а за „простия работен народ“ - отделни листове, които със „съвършено достъпен език“ да излагат основните начала на християнската вяра. Така се раждат брошурната библиотека „Истина“ и поредицата хвърчащи листове "Лъчи на истината". 
С цел да се подобри управлението и осъществяването на културната му политика, през 1933 г. при Св. Синод е учреден Комитет за организиране на религиозно-просветна дейност и пропаганда на църквата, често наричан за по-кратко само Просветен комитет. За негов председател е определен Неврокопският митрополит Макарий, а за членове - синодалният секретар, началникът на КПО и рьководителят на вътрешната мисия на църквата ${ }^{16}$.

Честата смяна на кадри, концепции и управленски стилове в културните институции на БПЦ възпрепятства нормалното развитие на нейната дейност. Не са редки случаите, когато различни състави на Св. Синод вземат идентични или сходни решения за разкриване на щатове, учредяване на длъжности и създаване на структури.

Книгоиздателската и книгоразпространителската дейност на БПЦ продължава да куца. Наред с всички други обективни и субективни причини, като най-голямо препятствие постепенно изпъква липсата на собствена печатна и разпространителска база. В края на 1937 г. в Св. Синод се обсъжда идеята за учредяване на издателство на акционерно дружество с частна столична печатница. Дебатите потвърждават, че необходимостта от поставянето на синодалната издателска дейност на по-широки и модерни основи е окончателно назряла ${ }^{17}$.

Върховната църковна управа достига до извода, че трябва да възприеме „една по-друга форма на издателство“, т.е. да затвори цикъла от отпечатването до разпространението на изданията си. Решителна крачка към осъществяването на новата издателска стратегия е направена през лятото на 1938 г., когато върховната църковна управа одобрява докладна записка на М. Попов за създаване на специализирана книжарница, която да пласира продукцията на Синодалното книгоиздателство ${ }^{18}$. За целта в края на с. г. е учреден и фонд „Синодално книгоиздателство“ с капитал от 17 млн. лв., формиран от книжната наличност в склада, задълженията на митрополиите и епархийските съвети и други подобни ${ }^{19}$. Синодалната книжарница отваря врати на 15 април 1939 г. в сградата на Богословския факултет на пл. „Св. Неделя“"20.

В следващите години върховната църковна управа подновява опитите си да се сдобие със собствена печатница. Направени са постъпки в чужбина. Новата световна война обаче разстройва европейския пазар и усложнява начинанието. Не успява и опитьт за купуване на печатарска машина от Германия. Едва на 2 септември 1942 г. Св. Синод придобива на изгодна цена печатницата на Гавазов в София и така затваря издателския цикъл, каквато е неговата стара мечта. В края на същата година се приема и разгърната програма за пласиране на печатната продукция, която по-пльтно ангажира митрополитите, като ги задължава да разкрият епархийски книжарници. В разпространението и популяризирането на синодалната книжнина сега са включени всички църковни органи от върховната управа до храмовите настоятелства и енорийските свещеници ${ }^{21}$.

Книгоиздателската и книгоразпространителската дейност не е самоцел за БПЦ. В нейните ръце тя е могъщо сечиво за моделиране на личното и общественото съзнание в България по образеца на християнските начала и добродетели. Затова за върховната църковна управа не е достатъчно само да уреди организационно и материално издателската си дейност, но и да гарантира ефективното нравствено въздействие на отпечатваната и разпространявана книжнина. Така църквата достига до най-съкровената част на културата - творческия процес.

Още през 20-те години БПЦ прави опити да събуди интерес в средите на художественото творчество и да стимулира авторите да пишат по религиозно-нравствени проблеми. По инициатива на тогавашния директор на синодалното книгоиздателство С. Абаджиев дори са учредени две годишни награди (премии) - едната от 6 хиляди, другата от 4 хиляди лв. - за най-добрите литературни произведения на религиозна тематика. Предвидено е премиите да се присъждат от специална комисия, съставена от утвърдени литературни критици и вещи богослови ${ }^{22}$. Както обаче често се случва в синодалната практиката, тази инициатива остава само в протокола. Едва в края на 30-те администраторът на „Църковен вестник“ докладва в Св. Синод, че мнозина писатели повдигали въпроса защо върховната църковна управа не предвиди в бюджета си няколко парични награди за най-хубавите произведения с религиозно-нравствен дух през годината. Синодалните архиереи решават да поправят този пропуск при гласуването на бюджета за 1939 г. ${ }^{23}$

Макар без премии и награди, БПЦ използва други начини за материално стимулиране на българската култура. Само за пет години след възстановяването на Синодалното издателство с ръководител М. Попов неговото ведомство откупува 365 съчинения на различни 
автори, които след това разпространява безплатно или на достъпна цена в епархиите 24 Пак по това време са поръчани, издадени и щедро хонорувани от Св. Синод няколко литературни сборника с произведения на български автори, съставени от Ангел Каралийчев, Йордан Стубел, Димитър Дюлгеров, Знеполски епископ Софроний ${ }^{25}$ и др.

През 30-те години Св. Синод се стреми да приобщи българските писатели към църквата и религията не само материално, но и духовно. Тогава се утвърждава практиката на авторите, които търсят изява по страниците на синодалните издания, да се даряват комплекти от религиозна и богословска книжнина, с цел „по-основно да се запознаят със Светото Писание и с духа на вярата, за да намират и художествено да разработват подходящи сюжети“. В синодалния списък на такива близки до църквата автори от 1935 г. фигурират имената на Йордан Йовков, Ангел Каралийчев, Йордан Стубел, Елисавета Багряна, Дора Габе, Георги Райчев, Константин Петканов, Светослав Минков, Асен Разцветников, Добри Немиров, Дамян Калфов, Панчо Михайлов, Димитьр Пантелеев, Славчо Красински, Спас Кралевски и Илия Волен ${ }^{26}$.

По принцип БПЦ - като институция и като представителни личности - храни положително мнение за мнозинството от българските писатели и не ги смята за носители на атеистични и противоцърковни идеи. Без да отрича, че взаимоотношенията между църквата и творците на културата в България не са толкова тесни и интензивни, както в някои други страни, протопрезвитер проф. д-р Ст. Цанков прави ясно разграничение между „нисшите слоеве на българската интелигенция“, обладани от атеизма на марксизма и антиклерикализма на либерализма, от една страна, и „пьрвите наши писатели“, генетично и духовно свързани с християнската вяра, от друга. „Не, че и те не са засегнати от тоя дух на своето време - обобщава авторът, който сам е ръководил културната политика на църквата, - но техните съмнения и блуждения носят съвсем друг характер и стоят в органическа, дълбока връзка с основните проблеми на религията, - загадката на живота и смъртта, на доброто и злото, на преходността и вечността, на смисъла на битието, на трагедията на страданието, на съществуванието и диханието на Божеството, а някои от тях са дълбоко развълнувани и пред проблемата на личността на самия Христа и на Неговото историческо дело. А почти всички те изказват неотразимо нежно чувство към вярата на своя народ и към личните си детски спомени и дълбоки следи на набожност, откърмена в патриархалната среда на своите родителски семейства“"27.

Важно място в културната дейност на БПЦ заема църковният периодичен печат. Балканската, Междусъюзническата и Първата световна война нанасят ськрушителен удар върху църковно-религиозния печат в България, който изживява своя разцвет през първото десетилетие на XX в., свързан с появата на синодалния официоз „Църковен вестник“ (1900 г.). Много провинциални издания изчезват още в мобилизационния период. Други сериозно се компрометират с противоречиви политически ангажименти и неприкрита военна пропаганда. Обтегнатите отношения между БПЦ и земеделския режим в началото на 20 -те години на XX в. се отразяват пагубно върху църковно-религиозния печат. Той никога вече няма да достигне количествените и качествените параметри на предходната епоха. Кризата не подминава дори „Църковен вестник“, който изживява няколко мъчителни години, докато отново стъпи на крака.

Първият по-сериозен опит за възраждане на синодалния официоз принадлежи на главния редактор Стефан Цанков. В заседанието на Св. Синод на 26 юли 1920 г. той докладва за състоянието и проблемите на редактирането, администрирането, разпространението и финансовото състояние на „Църковен вестник“ и приложенията му „Духовна култура“ и „Книжици за деца“. По негова идея са направени промени в редакционната колегия, като за редактори, администратори и сътрудници са привлечени преподаватели от Софийската духовна семинария. Главният редактор настоява вестникът да продължи да се списва с дотогавашния формат и периодичност, т.е. 16 страници веднъж седмично. Пак по негова инициатива епархийските началства са поканени с окръжно да съдействат за набирането на повече обяви, съобщения, призовки и пр. от църковните среди. Отделно от това от МВРИ е поискано да отпусне като безвъзмездна помощ 500000 лв. за периодичните издания на Св. Синод, а от МНП и Министерството на войната - да препорьчат „Църковен вестник“"на подведомствените си учреждения за абонамент ${ }^{28}$.

Както може и да се очаква, правителството на Стамболийски отказва да даде исканата субсидия 29. В следващите три години проблемите на „Църковен вестник“" често попадат в 
дневния ред на върховната църковна управа, но тя не е в състояние да му помогне. Заради всеобщата инфлация и поскъпването на хартията Св. Синод е изправен пред дилемата едновременно да повиши цената на своите издания, но да ги запази достъпни за възможно най-широк кръг читатели ${ }^{30}$. Това не може да стане по друг начин, освен с икономии за сметка на качеството. От пролетта на 1921 г. обемът на „Църковен вестник“ пада на 8 страници веднъж седмично, а на „Духовна култура“ - на 3-4 коли три пъти годишно. На 12 април 1921 г. С. Цанков е освободен по собствено желание от длъжността главен редактор на синодалния официоз. След два неуспешни опита да му намерят достоен приемник, на 22 юли 1922 г. вестникът е поверен на Видинския митрополит Неофит. С новото ръководство синодалните издания трьгват нагоре. Обемът на „Църковен вестник“ се увеличава от 8 на 16 страници, а на „Духовна култура“ - на 5 коли 4 пьти годишно. Увеличават се също цената, месечният абонамент, заплатите и хонорарите, но бюджетът им остава с положителен баланс ${ }^{31}$.

Политическата промяна в страната също влияе благоприятно върху синодалния официо3. В края на годината Св. Синод му предоставя по-щедър бюджет, като решава да започне издаването на ново приложение - сп. „Църковен архив“, в което да се печатат документи и материали от епохата на народното възраждане и църковното обновление и устройство. Макар с известно завишаване на цената на вестника, е подобрено и качеството на хартията. Все пак върховната църковна управа приема да го разпространява под себестойността му за учащата се младеж, която по нейна преценка се нуждае от „здрава духовна храна“32.

От 1 април 1927 г. Видинският митрополит Неофит е заместен на длъжността главен редактор на „Църковен вестник“ от проф. Иван Снегаров ${ }^{33}$. През 30-те години на XX в. главното редакторство се поема последователно от Христо Попов, проф. Димитьр Дюлгеров, Траянополския епископ Антим, Матей Попов, Ловчанския митрополит Антим. От 1938 г. и в годините на Втората световна война редактор на „Църковен вестник“ е Христо Попов с помощник протодякон Георги Ибришимов. Като сътрудници са привлечени всички по-видни български църковници, учени и публицисти ${ }^{34}$. Подобряването се и материалното състояние на изданието. Ако през 1926 г. „Църковен вестник“ завършва с около 65 хил. лв. дефицит (при 726372 лв. разходи и 660972 лв. приходи), през 1934 г. вече отчита остатък от 200 хил. лв. (при 844619 лв. разходи и 1045009 лв. приходи) $)^{35}$. През 1938 г. изданието става член на Съюза на техническия и периодичен печат в България, в секция „А““, където има свой представител ${ }^{36}$.

Флагманът на църковния печат безспорно е най-авторитетното издание от този род в България, при това не само с името на институцията, която го издава, но и със съдържанието, с което редакторите и авторите му го представят на читателската публика. Действително, събрани заедно, броевете на „Църковен вестник“ всяка година дават живот на един обемист том, който по форма и съдържание, а следователно и по познавателна стойност, се доближава до равнището на солидно енциклопедично издание или алманах. Добра представа за него дава съдържанието на вестника през 1939 г. Общо за годината в „Църковен вестник“" са публикувани 140 статии по научно-богословски, религиозно-обществен, религиозно-философски и етичен характер, 13 проповеди, речи, слова, сказки и беседи, 21 исторически и литературни произведения, пътни бележки, църковни и народни тържества и събрания, 18 материала от социален, политически, стопански, правен и финансов характер, 24 рецензии и отзиви за книги, 34 статии по въпроси на белетристиката и изкуството и т.н. Освен това вестникът поддържа постоянни рубрики за междуцърковни отношения, за живота на чуждите църкви, писма и дописки на читатели, официален отдел за окрьжни и съобщения, из печата, седмичен преглед на събитията, църковно-обществена летопис. Големият познавач на църковната действителност у нас Ст. Цанков може и да е прав в твърдението си, че синодалният седмичник „не успява да стане настолно четиво в българската православна къща““37, но днес всеки историк, който е прелиствал неговите страници, може да потвърди, че „Църковен вестник“ е безценен документален извор, без чието ползване никое изследване на обществения живот в България през тази епоха няма да бъде пълноценно.

Стабилизирането на синодалния официоз оказва благотворно влияние и върху развитието на църковно-религиозната периодика въобще. Голяма популярност сред по-образованите читатели добива сп. „Духовна култура“, което до 1934 г. излиза в 4 книжки годишно, а след това в 10 . В него се печатат популярни статии от религиозно-философски 
характер, засягащи всички аспекти на духовната култура. По традиция главният редактор на „Цьрковен вестник“ е и редактор на „Духовна култура“.

Освен върховната църковна управа сериозен дял в българската духовна периодика внася и Съюзът на свещеническите братства, който издава седмичния вестник „Пастирско дело“ и месечното списание „Православен пастир“. Утвърждават се и епархийските издания, сред които с най-голям авторитет се ползват „Народен страж“ на Софийската митрополия, „Братско слово“ на Пловдивската митрополия, „Духовно възраждане“ на Врачанската митрополия, „Вяра и живот“ на Русенската митрополия, „Търновски епархийски вести“" на Търновската митрополия. С различен успех търсят своя облик и място в читателските среди и други църковно-религиозни периодични издания, като сп. „Християнка“" - орган на Съюза на православните християнски братства, сп. „Зов“ - орган на православната християнска учаща се младеж, сп. „Детско знаме“ - за най-младата публика, редактирано от Марин Христов (Илия Волен). Освен по чисто църковно-религиозни въпроси, тези издания публикуват статии, рецензии и отзиви за новопоявили се книги или културни събития и отварят страниците си за писатели и поети, чието творчество не влиза в противоречие с християнската доктрина. Някои от тези вестници и списания обаче не биха просъществували и година без паричната подкрепа на Св. Синод ${ }^{38}$.

Научната богословска мисъл на БПЦ се развива главно от „Годишника на Богословския факултет“ и другите богословски издания на Софийския университет, а чрез списанията „Духовна култура“" и „Православен мисионер“ търси и намира популяризация и извън академичните кръгове. Създаден през 1923 г. Богословският факултет се развива не само като авторитетна научна институция, но и като един вид мозъчен тръст, който насочва и развива културно-просветната дейност на църквата. Неслучайно неговите преподаватели са редактори и сьтрудници на „Църковен вестник“ и на всички по-сериозни издания на БПЦ39.

Въпреки очевидните успехи, църковно-религиозната периодика също има своите слабости, които не убягват от погледа на компетентните наблюдатели. През 1927 г. проф. Иван Марковски излиза със статия, в която се изказва доста негативно за количеството, качеството и разпространението на църковните вестници и списания. Според него дори синодалният официоз вече не се четял така охотно, както в предвоенния период, и не отговарял на завишените критерии на читателите. Изтъкнатият български богослов и църковен публицист основателно възразява срещу дългите статии с продължения, които са в състояние да убият интереса към всяко периодично издание. Той изобщо смята, че книгите са по-полезни от вестниците, които след прочитане обикновено биват захвърляни и забравяни. Затова проф. Марковски предлага Св. Синод да сгрупира интелектуалните и материалните си ресурси в „Цьрковен вестник“ и още „три или четири добре списвани печатни издания“, с които ще постигне по-добри резултати, отколкото с голяма на брой, но слаба по качество периодика ${ }^{40}$.

Сходни идеи пет години по-късно развива и синодалният секретар епископ Борис (впоследствие Неврокопски митрополит). В свой доклад до върховната църковна управа той предлага съсредоточаване на редакциите и администрациите на синодалните периодични издания в Богословския факултет, като при това освен „Цьрковен вестник“ останат да излизат само още три списания, профилирани и съобразени с културното равнище и духовните нужди на българските читатели ${ }^{41}$.

Въпреки че критиката на проф. Марковски намира своите опоненти, а идеята му за концентрация на сили и средства, за която пледира и епископ Борис, не се осъществява, цялостното развитие на цьрковно-религиозната периодика показва, че в основата си те са били прави. В края на 20-те и през 30-те години на XX в. структурата на религиозните периодични издания в страната се променя в полза на списанията. Ако през 1926 г. в България излизат 17 вестника и 22 списания с църковно-религиозно съдържание, то през 1936 г. те са вече съответно 13 и $36^{42}$. Тази тенденция донякъде се дължи и на обстоятелството, че освен чрез книжнината и периодиката, БПЦ тогава намира и други, още по-модерни пътища за културно въздействие върху обществото.

В епохата между двете световни войни това безспорно е радиото. Възможността да постави най-популярната тогава масмедия в служба на религията е подсказана на върховната църковна управа от Съюза „Родно Радио“. На 29 декември 1931 г. в дневния ред на синодалните заседания е обсъдено писмо, с което професионалното сдружение на българ- 
ските радиожурналисти предлага да излъчва в ефир църковните служби и проповедите от храма „Св. Александър Невски“ в София. Срещу безвъзмездното им предаване Св. Синод трябва да плати техническото оборудване на стойност около 25 хиляди лева - една не много голяма сума за възможностите на църквата ${ }^{43}$. Първоначално предстоятелят на ставропигиалния храм посреща новината с известни резерви - да не се осквернят църковните служби, ако се слушат по радиото „из ресторанти, кабарета, съмнителни домове, в домовете на нехристияни и пр.“. Върховната църковна управа обаче разсейва неговите опасения с опита от чужбина, където подобни радиопредавания отдавна вече са утвърдена практика. Затова и Св. Синод се показва щедър към българските радиожурналисти. В заседанието си на 22 април 1932 г. той решава да отпусне на Съюза „Родно Радио“ дори по-голяма сума от първоначално поисканата - 30000 лв. за монтиране на пет микрофона в храм-паметника „Св. Александър Невски““44.

Скоро в българския ефир освен църковните служби започват да звучат и първите радиобеседи по нравствени, богословски и църковноисторически въпроси. Техни автори са протопрезвитер проф. Ст. Цанков, протойерей Христо Димитров и проф. Димитьр Дюлгеров. Честта да постави началото обаче по право и по достойнство се пада на наместникпредседателя на Св. Синод Видинския митрополит Неофит. На 27 март 1932 г. той прочита пред микрофона своята беседа „Гласът на историята за ролята на църквата““45.

През 1936 г. по доклад на инспектора на КПО Борис Попстоименов, който участва в едно междуведомствено заседание на Радиопрограмния съвет при Дирекцията на пощите и телеграфите, интеграцията между радиото и църквата става още по-тясна. Така новостите от църковното управление и религиозната просвета попадат в информационната рубрика на Радио „София“ наред с новините от министерствата и другите държавни ведомства. Като официален посредник между новинарската емисия и Св. Синод е определен инспекторът на КПО. Той е натоварен също да подготви и една редовна радиопрограма за неделни проповеди и сказки, като покани за участие най-известните църковни автори ${ }^{46}$. От пролетта на следващата година, по покана на управителния съвет на Радио „София“, БПЦ се ангажира с още една рубрика - седмичния цикъл радиобеседи „От Аспаруха до Цар Бориса III“", който представя фигурите на велики и заслужили българи. Така спонсорираните от Св. Синод ефирни рубрики стават две - една седмична поредица от религиозни проповеди и друга на църковноисторическа тематика ${ }^{47}$.

Все пак върховната църковна управа си дава сметка, че радиото не може и не бива да заменя храма, а светостта на богослужението изисква определени граници, които трябва да бъдат спазвани дори от всепроникващия ефир. Тези и други подобни проблеми, произтичащи от срещата на традицията с модерното, стават предмет на специално синодално заседание на 16 декември 1937 г. Синодалните архиереи се обединяват около становището, че предаването на богослужение по радиоапарати в кръчми, кафенета и увеселителни заведения е „кощунствено излагане на самите църковни служби“, което трябва да бъде забранено и строго преследвано от органите на Министерството на вътрешните работи и народното здраве (МВРН3). Това не трябва да се допуска и в читалищата, особено ако в селището има църква, защото „омаловажава значението на храма и храмовото богослужение“. Важно условие, за което Св. Синод изрично и твърдо настоява, е, че проповедта е неразделна част от богослужението и радиопредаванията не трябва да я игнорират, каквато практика започва да се забелязва ${ }^{48}$.

Мощното навлизане на църквата в ефира не минава и без някои проблеми, до болка познати на вестникарите и книгоиздателите. Става въпрос за цензурата. Първа жертва на нейните вечно променливи конюнктурни изисквания, свързани с вътрешната и външната политика на страната, става дякон Кирил Велев от храм-паметника „Св. Александър Невски“. На 12 септември 1937 г. бдителен цензор открива в текста на неговата радиобеседа изрази, които можели да засегнат „една съседна страна“. Въпреки това упоритият дякон си позволил да прочете в ефир цензурирания текст. Оскърбителните за съседната страна изречения, които така дълбоко възмутили държавната цензура, гласели: „Тия дни - 9, 10 и 11 август 1877 г. русите и българите рамо до рамо се бориха с многобройните фанатизирани и свирепи орди на Сюлейман паша... И тъй биде освободен един народ, който 500 години пъшка под игото на най-некултурното и варварско владетелско племе на Европа““. Това дава основание на МВРИ да поиска от Св. Синод най-строго наказание за провинилия се свещенослужител ${ }^{49}$. 
Въпреки подобни неприятности от страна на цензурата, на която БПЦ е принудена да плати неизбежна дан, нейното присъствие в радиоефира от година на година се увеличава. Скоро по Радио „София“ започват да звучат концерти и пиеси с участието на църковни хорове при различни столични храмове ${ }^{50}$. От 1939 г. религиозни служби, проповеди и беседи започват да се излъчват от Радио „Варна“ и Радио „Стара Загора““51. Приблизително от това време датира и практиката радиото да предава традиционното „Послание до православния български народ“" на Св. Синод по случай Коледа и Рождество Христово. Един от най-честите гости на ефира е Софийският митрополит Стефан. Неговите беседи се ползват с голяма популярност сред българските радиослушатели, а чрез благословиите му за Бъдни вечер, Великден и другите църковни празници гласът му звучи в домовете на много семейства. Медийната популярност обаче има и тъмна страна. Тъкмо митрополит Стефан със своите твърди позиции по обществени и политически въпроси се превръща в най-цензурирания и най-често нападания в ефира български архиерей ${ }^{52}$.

Сътрудничеството между БПЦ и ефирната медия става още по-тясно, когато за директор на радиоразпръскването в България и управител на Радио „София“ е назначен Йордан Стубел, популярен в църковните среди поет, чиито произведения Св. Синод издава и препорьчва. По повод на неговото назначение синодалният официоз изказва надежда, че той ще доведе до пълен разцвет поверения му културен институт, „чийто микрофон е и важна мисионерска катедра за просветна роля на родната православна църква“"53.

В периода между двете световни войни културната стратегия на БПЦ за религиознонравствено въздействие върху обществото не подминава и киното. Първоначално някои по-консервативно настроени лица и среди се обявяват против седмото изкуство като възможен носител и разпространител на антиклерикален и противоцьрковен дух. Най-убеден противник на киното, както впрочем и на всяко друго културно или техническо нововъведение в живота, е Варненско-Преславският митрополит Симеон. През 1926 г. между него и епархийския съвет възниква остър спор по въпроса допустимо ли е от нравствено-религиозна гледна точка свещениците да ходят на кино. Членовете на епархийския съвет поддържат становището, че няма канонични или други причини, поради които духовниците и техните семейства да не могат да гледат филми, които „оказват възпитателно въздействие и обогатяват знанията на човека“. Митрополитьт, напротив, е убеден, че „духовенството, като служител Христов, е длъжно да носи с търпение известни лишения от удоволствия и не бива да посещава кинематографите, гдето се представят безнравствени филми“.

Спорът е отнесен до Св. Синод. В заседанието си на 1 април той взема мъдро решение, което ще открие пътя на църквата към още едно могъщо средство за културно въздействие върху обществото. Върховната църковна управа приема, че възгледът на Варненско-Преславския митрополит Симеон е прав само за филми с „безнравствени сюжети и съблазнителни картини“. За останалите становището на Св. Синод е категорично положително: „Има обаче кинематографски филми, които излагат картини от научен, нравствено-религиозен и възпитателен характер. Тия филми не могат да бъдат противни на църковните канони, следователно, няма основания да се забранява на свещеническите семейства, па и на самите свещеници, да присъстват на кинематографически представления от тоя род“54.

Църквата не само допуска свещенослужителите до киносалоните, но и сама навлиза във филмопроизводството. С участието си в някои продукции тя цели да упражнява пряк контрол върху интерпретирането на морални и религиозни въпроси. Така през 1927 г., когато Дирекцията на Модерния театьр решава да филмира романа на Иван Вазов „Под игото“, сцените в църкви и манастири са заснети в присъствието на началника на КПО. Неговият мандат е „да избегне всичко, що би могло да профанира вярата и богослужението в църквата““55. За да упражнява ефикасен и централизиран контрол, Св. Синод си издейства правото да има свой представител в комисията за кинематографите при МНП. От 1931 г. тази функция е поверена на подначалника на КПО Матей Попов ${ }^{56}$. От тук до прякото участие на църквата и във филморазпространението има само една крачка и тя е направена от Православното благодетелно дружество „Св. Василий Велики“ в София. През пролетта на 1934 г. то се снабдява с подвижен киноапарат и започва да прожектира из страната филми с религиозно-нравствено съдържание, предварително проверявани и одобрявани от началника на КПО

$\mathrm{C}$ течение на времето се налага практиката (която впрочем отдавна съществува по отношение на книгите) в Св. Синод да се обсъждат новопроизведени български филми и 
ако се прецени, че са „почтени и будят религиозни чувства“, да получават синодална препорька и да се радват на положителни препорьки, отзиви и рецензии в църковния печат. Напредничавостта на върховната църковна управа стига дори дотам, че разрешава прожектирането на филми с религиозно съдържание в дните на Страстната седмица - нещо, което в предходните години категорично забранява ${ }^{58}$.

Толерантна към произведения от всякакви жанрове, които утвърждават добрите нрави и будят уважение към църквата, БПЦ е непримирима към всички - по нейните критерии - рушители на личния и обществения морал. Още в предвоенния период Св. Синод води титанична борба срещу търговията с „пощенски картички със срамни фотографии и рисунки с мръсни и срамни сцени“, която тогава процъфтява. „Разпространението на карти с непристойни рисунки и съдържания е взело широки размери в България - с горчивина констатира върховната църковна управа. - Не само в София, а на всъде по градовете и селата из провинцията охотно се разпродават на най-открити места такивато карти, в явна съблазън на благочестивото изпълнение“. Такава строга пуристка си остава БПЦ и по отношение на интонационната среда, в която живее българинът през втората четвърт на XX в. Неведнъж и дваж на Св. Синод се налага да прави постьпки пред МВРНЗ за изземване от продавачи и притежатели на грамофонни плочи с непристойно съдържание. Действително, дори само със заглавията си някои от тях са в състояние да уронят престижа на църквата и да окажат „зловредно влияние върху добрите нрави“, като например: „Покръстеният циганин“ и „Телефонна грешка в монастиря“ на фирма „Орфей“ и „Разболял се дядо владика“" на фирма „Лондон-рекорд““59.

Именно тази драстична разлика между нравствените стандарти на църквата и духовните потребности на масовия потребител разкрива една от основните характеристика на културно-просветната дейност на БПЦ в периода между двете световни войни. Изграждана от горе надолу, по инициатива на върховната църковна управа и при слабата активност, а в някои случаи и пълното бездействие на епархийските и енорийските структури, тя не може да разчита на значителни и трайни успехи. Организацията, управлението и осьществяването на културната дейност на църквата образно може да се оприличи на обърната пирамида, която има тясна опора сред своите адресати. Отрицателна роля, разбира се, играят обременените отношения с държавата и вътрешноцърковните противоречия, особено борбите по върховете на църковната йерархия, разделена през 30-те години на две групировки, персонализирани от Софийския митрополит Стефан и от Варненско-Преславския митрополит Симеон. В резултат религиозната култура успява да проникне и да се вкорени само в определени прослойки на българското общество, докато цялостното обновление, към което се стреми или поне говори Св. Синод, остава далечна и непостижима цел.

Това има предвид и Софийският митрополит Стефан, когато в края на 1939 г. изказва критични думи за църковното книгоиздателство, които биха могли да се приемат и като обобщение за цялата културна дейност на БПЦ в периода между двете световни войни: „Ние почнахме да градим религиозно-нравствения мироглед в изпълнението от керемидите: основа се, без да има искане и капитал, дирекция на църковно-религиозно книгоиздателство, лишена от живия дух, от която резултатът е нула“. Посланието на митрополит Стефан е, че преди да се разпространява църковна литература - респективно култура - трябва да има „богоискане и богослужение“60.

Ако трябва да преведем църковната стилистика на Софийския митрополит на езика на съвременното гражданско общество и доминиращото светско съзнание, най-близо ще бъде интерпретацията, че той апелира за едно по-дълбоко равнище на културно мисионерство, което неизбежно достига до онази инфраструктура на българската култура, без която е невъзможно нейното съществуване и развитие - националното образование и възпитание. Не от „керемидите“, а от основата трябва да започне изграждането на духовната култура. Това е същата онази основа, която ражда и крепи българската култура, българската нация и българската държава - училището. И точно тук БПЦ търпи най-голямото си поражение, което ще бъде съдбоносно както за нея, така и за България.

Още от първите стъпки на българската държава след Освобождението БПЦ се противопоставя срещу разкъсването на връзката между училище и църква, образование и религия, морал и вяра. Върховната църковна управа е особено недоволна, че вероучението е слабо застъпено в основните училища и прогимназиите и е напълно игнорирано от гимназиите и висшите училища. Затова синодалното послание от 1925 г. във връзка със 
злодеянието в „Св. Неделя“ изрично подчертава, че между лошото училищно възпитание и погрешните учебни програми, от една страна, и кървавите комунистически атентати, от друга, има пряка и непосредствена причинно-следствена връзка. По този повод синодалните архиереи решават да приготвят и връчат на правителството обстойно изложение, с което да му посочат какви промени са необходими в учебните програми и изобщо в цялата образователно-възпитателна система ${ }^{61}$. За целта е съставена комисия с председател Старозагорския митрополит Павел. Два месеца по-късно той представя в Св. Синод подробен доклад с приложена към него проекто-програма по вероучение в педагогическите училища, която предвижда вместо 1 час седмично да се преподава 6 часа $^{62}$.

На 23 юли 1925 г. Св. Синод одобрява текста на подготвеното изложение до МВРИ по въпроса за учебно-възпитателната мисия на българското училище. Още в началото документът призовава за сплотяване на всички „здрави културни фактори“ срещу религиозно-нравствения упадък на обществото. „Страшно морално падение, зверска кръвожадност, липса на всяка вяра в доброто и в Бога, липса на любов към красивата ни родна земя, липса на висш идеализъм - ето нравствената и духовна атмосфера, сред която живее немалка част от гражданството ни, предимно младежта“. С такива думи синодалните отци описват духовната криза, обладала българското общество и родила Септемврийския метеж и атентата в „Св. Неделя“, като алармират, че най-засегната от анархо-комунистическия дух, идещ от Русия, е младежта. Върховната църковна управа се позовава на скорошна анкета в столична гимназия, която установила, че $18-20 \%$ от учениците били заразени от комунизма.

Според синодалните архиереи в Европа няма друга страна, в която училището да е скъсало до такава степен връзките си с християнската религия, както България. Това твърдение те подкрепят и с друга статистика, която пък доказва, че с 3 часа вероучение седмично в основните и средните училища България се нарежда на последно място сред европейските държави, в които същият предмет заема завидно място (Германия - 18 , Белгия - 16, Сърбия - 10, Гърция - 9, Румъния - 7 и т.н. $)^{63}$. Всъщност няма друга страна с преобладаващо православно население, освен СССР, където атеизмът е официална идеологическа доктрина, в която вероучението да заема такова нищожно място в учебните програми и при това да се преподава от светски лица ${ }^{64}$.

За да пресече корените на духовно-социалната криза, обладала българския народ, Св. Синод предлага цяла поредица мерки, които да намерят място в Закона за народното просвещение и в образователната практика на българското училище. На първо място изрично и безусловно да се подчертае, че целта на училището е не само да обучава, но и да възпитава, да дава религиозно-нравствено възпитание. От това следва, че трябва да се увеличат часовете по вероучение по примера на другите европейски страни. Върховната църковна управа настоява за 2 часа седмично във всички класове на основните и средните училища (следователно общо 16 часа за целия образователен цикъл от I до VIII гимназиален клас). Нататък възпитателната концепция на Св. Синод препоръчва да се обърне внимание на онези дисциплини, които имат съприкосновение с вероучението, като естествознание, психология, етика и пр., и които повечето учебници третирали в „грубо-материалистически и антиклерикален дух“. Необходим е сьщо по-внимателен подбор и поефикасен контрол на учителския персонал, тъй като по мнението на върховната църковна управа дълго време българското училище било ръководено от безбожници. Затова вероучението трябва да се преподава от свещеници и богослови, притежаващи необходимия образователен ценз, и само по изключение от лица без богословско образование, но затова пък „вярващи и добри християни“. Естествено, предвидени са и мерки за въвеждане и упражняване на ефикасен надзор върху преподаването на вероучението. Особено значение Св. Синод придава на богослужението и предписва поне веднъж седмично учащата се младеж да бъде водена организирано на църква. От Министерството на народното просвещение се иска също и подкрепа за Съюза на православните християнски дружества и учащата се младеж в България, за да могат по-успешно да се противопоставят на чужди и противохристиянски влияния в страната.

„Едно училище, проникнато от Христовия дух, струва повече от милионна полиция, повече от могъща армия; то би предотвратило много метежи и кръвнини; то би спестило много народни сълзи; то би било най-добрият спасителен балсам и за нашите днешни народни рани“ - обобщава в заключение синодалното изложение. За да популяризира своите възгледи по въпроса за образователната и възпитателната мисия на българското училище, 
Св. Синод решава да публикува пълния текст на изложението в „Църковен вестник“, а сьщо и да го разпространи под формата на брошура сред народа ${ }^{65}$.

Новата възпитателна концепция на БПЦ претърпява пълно фиаско. Наистина, въпросът за включване на вероучението в програмата на средните училища е разискван във Висшия учебен съвет при МНП, но както и преди е ставало, с отрицателен за църквата резултат ${ }^{66}$. Загубила първия рунд, върховната църковна управа мобилизира сили за следващия. На 8 декември 1927 г. тя свиква Архиерейско събрание, в чийто дневен ред първо място заемат въпросите за вероучението в училището, религиозно-нравственото възпитание на младежта и противодействието срещу разрушителните действия на безбожниците, сектантството и нравствената развала. Включени са и други точки, като положението с Екзархийския устав от 1921 г., материални и финансови въпроси, проблеми от вътрешноцърковния живот, някои въпроси на междуцърковните отношения и др. Архиерейското събрание заседава до 27 декември 1927 г., но повечето от решенията му имат декларативен характер, насочени към затягане на църковната дисциплина. Освен познатите претенции към правителството по отношение на вероучението в основните и средните училища, Архиерейското събрание настоява за специален закон за вероизповеданията ${ }^{67}$.

Неравната борба между църквата и училището, или по-конкретно между религиозната и гражданската концепция за възпитанието на българската младеж, продължава още десет години. Върховната църковна управа се домогва до известен успех, едва когато сянката на новата световна война ляга върху страната и кара нейните управници да се замислят посериозно върху значението на моралните устои за държавата и обществото.

На 11 февруари 1938 г. е издадена наредба-закон за въвеждане в програмите на гимназиалното образование на учебния предмет „Религия с история на българската църква“. Този законодателен акт дава също така право на завършилите Богословския факултет да преподават новия предмет в гимназиите, както и вероучение в прогимназиите. На следващата година Богдан Филов в качеството си на министьр на народното просвещение издава окръжно, което признава значението на религиозното възпитание и препоръчва да се оказва съдействие на ученическите православни християнски дружества, да се насърчава участието в църковните хорове, да се водят учениците редовно на църква, да се канят свещеници за духовни беседи и други подобни ${ }^{68}$. В резултат на новата възпитателна стратегия в плановете за учебната 1939/40 година предметът „Религия с история на българската църква“ намира място с два часа седмично в програмата за IV и с по един час за V, VI и VII клас ${ }^{69}$. За съжаление, това става твърде късно - в самото навечерие на новата световна война и само пет години преди установяването на атеистичния комунистически режим в България.

Лишена от опора в образователната институция, БПЦ все пак разполага или поне се опитва да се снабди с други оръдия за въздействие върху обществото. Това са различните братства и сдружения.

Най-стари сред тях са свещеническите братства, датиращи отпреди Освобождението, масово разпространени след това и обединени през 1911 г. в съюз. Освен чисто църковните и професионалните проблеми, свещеническите братства си поставят редица цели за религиозно, културно и социално издигане на българското общество. В навечерието на Втората световна война Съюзът на свещеническите братства в България се състои от 67 местни организации, обединени в 11 епархийски структури с 2562 членове. В изпълнение на уставните цели на своето сдружение свещениците участват активно в редица просветни и благотворителни организации - 259 в православните християнски братства и ученически дружества, 352 в народните читалища, 321 в кооперациите, 126 в училищните настоятелства, над 150 в Червения кръст, около 200 в Общобългарския съюз „Отец Паисий“ и др.70

От началото на XX в. започват да се създават и православни християнски братства, които си вменяват в дълг, най-общо казано, да скъсят дистанцията между народа и църквата, да култивират с различни средства християнските ценности сред обществото. По форма и по съдържание те са всъщност реплика на аналогично движение в католическия свят, известно под наименованието „католическа акция“. През 1926 г. е учреден Съюз на православните християнски братства в България, който се ползва с подкрепата на висшата църковна управа. В средата на 30-те години той се състои от 770 братства с 39922 членове. Тяхната културна и социална дейност през 1938 г. се измерва с близо 12 хиляди сказки и беседи, 283 концерти, забави и пр., 341 екскурзии и поклоничества, 31 библейски курсове. През същата година Съюзът поддържа 265 братствени библиотеки и 126 църковни хора. 
Броят на разпространените книги с религиозно съдържание сред съюзни членове и симпатизанти възлиза на 53518 екземпляра. За подпомагане на сиропиталища, старопиталища, нощни подслони, безплатни трапезарии, болнични заведения и други подобни социални институции, както и на отделни нуждаещи се хора, Съюзът на православните християнски братства изразходва над 3 млн. лв. ${ }^{71}$

Сходни по организация и дейност са православните християнски младежки дружества. Те пък са заемка от протестантския свят и се развиват в България главно след войните. Първите дружества са студентски и младежки. През 1923 г. се учредяват наведнъж 9 ученически дружества, които на следващата година се обединяват в Съюз на православните ученически дружества в България. Тяхната цел е да съдействат за възпитанието на децата и младежта в християнски дух чрез организиране на сказки и беседи, поддържане на библиотеки, читални и трапезарии, уреждане на църковни хорове, екскурзии и други подобни инициативи. През 1928 г. Съюзът на православните ученически дружества наброява 35 клона с около 4000 членове. В следващите години, когато дружествата се поставят под прекия контрол и ръководство на епархийските архиереи, тяхната организационна структура устремно се разраства. През 1935 г., поне на хартия, съществуват едно студентско дружество с 80 членове, 26 юношески с 956 членове, 71 ученически с 6901 членове и 1342 детски със 106190 членове. Масовизацията обаче става за сметка на качеството и ефекта от културно-просветната и религиозно-възпитателната дейност ${ }^{72}$.

През 1934 г. е учреден Съюз на православните жени в България, който има за цел да подкрепя в нравствено и социално отношение българското семейство. Средствата му са идентични или сходни с тези на останалите православни дружества и съюзи в страната ${ }^{73}$.

Чрез тези съюзи, дружества и братства, както и със собствените си сили и средства, БПЦ се опитва да излекува българското общество от травмите на войните и националните катастрофи. Основните ѝ противници на това полесражение са нарастването на извънбрачните съжителства, увеличаването на разводите, намаляването на раждаемостта, ширенето на алкохолизма и други подобни явления, които за църквата не са друго, освен „нравствени и социални пороци“, породени от упадъка на християнския морал и отдалечаването от храма ${ }^{74}$.

Мястото и ролята на БПЦ в българската култура между двете световни войни не би следвало да се измерват само и единствено чрез тиража на издадените книги, броя на списанията и вестниците, обема на ефирното време. Църквата не е културно министерство, нито научен институт; нейната основна цел и мисия е религиозното възпитание, разпространяването, утвърждаването и вкореняването на християнските ценности в личния и обществения морал. Непоклатимата основа на нейната възпитателна културно-просветна мисия е изградена от християнската антропология.

За християнството човекът е отражение на божествена същност и поради това всички хора са равни пред Бога и пред църквата. Тази концепция пронизва съдържанието на църковната устна и писмена проповед още в предходния период, но през 30-те години в изданията на БПЦ отчетливо зачестяват публикациите за християнското равенство, които припомнят и развиват основните идеи от евангелските послания ${ }^{75}$.

Извадено от контекста на църковно-религиозния живот и проектирано върху обществено-политическата действителност в България в навечерието на Втората световна война, това просто религиозно послание придобива стойността на смел политически манифест. Неговото значение става още по-голямо, като се припомни, че произлиза от господстващо по конституция и авторитетно по традиция вероизповедание. Учението на църквата за християнското равенство е близко до манталитета и душевността на българина. То здраво и трайно се вкоренява в индивидуалното и общественото съзнание, но не защото идва от парламентарна трибуна или академична катедра, а защото се проповядва от църковния амвон. Чрез вероучението, богослужението и проповедта, чрез целия онзи сложен комплекс на църковно-държавно-семейни взаимоотношения и отговорности, които формират същността на религиозното възпитание, простите евангелски истини се превръщат в твърди житейски норми.

Това е най-големият и най-важният принос на БПЦ в българската култура. От дълбините на своята доктрина до външните си форми на изява тя е убеден, непримирим и последователен противник на всякакви форми на расово или народностно неравенство, на насилие и на унижаване на човешкото достойнство. Макар да нямат бляська на парламентарните дебати или шума на уличните демонстрации, християнската доктрина и 
християнският морал притежават всепроникваща и могъща вътрешна сила, която с векове се е наслагвала в съзнанието на народа. Затова възпитателната - или евангелизаторската според църковните понятия - роля на църквата, мобилизирана сякаш с предчувствието за наближаващата напаст на тоталитаризма, дава възможност на БПЦ да изпише едни от най-славните страници в своята история, без които и историята на България в годините на Втората световна война не би била същата.

${ }^{1}$ Въргов X. Конституцията на Българската православна църква (История и развой на Екзархийския устав) 1871-1921. - София, 1921. - С. 434.

${ }^{2}$ Първият църковно-народен събор в свободна България. - София, 1921. - С. $28-39$.

${ }^{3}$ Централен държавен архив (по-нататък - ЦДА), ф. 791К, оп. 1, а.е. 40, л. 432-440.

${ }^{4}$ Пак там, л. $305-385$.

${ }^{5}$ Пак там, а.е. 33 , л. 949, 1074.

${ }^{6}$ Пак там, а.е. 34, л. 893-894.

${ }^{7}$ Пак там, а.е. 39, л. 537.

${ }^{8}$ Пак там, л. 639-642.

${ }^{9}$ Пак там, л. 672-674.

${ }^{10}$ Пак там, л. 997.

${ }^{11}$ Пак там, а.е. 42, л. 204-205.

${ }^{12}$ Цанков С. Българската православна църква от Освобождението до настояще време. - София, 1939. - C. 210-211.

${ }^{13}$ Пак там. - С. 99, 263-264.

${ }^{14}$ Пак там. - С. 212.

${ }^{15}$ ЦДА, ф. 791К, оп. 1, а.е. 46, л. 112-113.

${ }^{16}$ Пак там, а.е. 53 , л. 272.

${ }^{17}$ Пак там, а.е. 59, л. 232, 237-238, 302-303.

${ }^{18}$ Пак там, а.е. 60, л. 562-564.

${ }^{19}$ Пак там, а.е. 61, л. 373-376.

${ }^{20}$ Църковен вестник. - 1939. - № 15-16. - 6 апр.

${ }^{21}$ ЦДА, ф. 791К, оп. 2, а.е. 10, л. 159-311-312.

${ }^{22}$ Пак там, оп. 1, а е. 42, л. 677-681.

${ }^{23}$ Пак там, а.е. 57, л. 1088.

${ }^{24}$ Цьрковен вестник. - 1939. - № 14. - 31 март.

${ }^{25}$ Каралийчев A. Кандило пред иконата. Отбрани разкази от български писатели. - София, 1938; Стубел Й. Небесни камбани. Сборник стихове. - София, 1937; Същият. Богородична люлка. Стихове. - София, 1940; Дюлгеров Д. Религиозно четиво. Сборник от избрани стихове, разкази и откъслеци с религиозно-нравствено съдържание от българската художествена литература / Д. Дюлгеров, Д. Иванов. - София, 1943; Софроний, епископ Знеполски. Литературен сборник за православните християнски дружества и братства / Софроний, епископ Знеполски, Б. Маринов. - София, 1935.

${ }^{26}$ ЦДА, ф. 791 К, оп. 1, а.е. 54, л. 417-419.

${ }^{27}$ Цанков С. Българската православна църква ... - С. 223; Същата теза, развита по-пространно, вж. у: Архимандрит Евтимий. Отрицатели на религията ли са българските поети и писатели? // Годишник на Софийски университет. Богословски факултет. - 1941-1942. - XIX. - С. 3-38.

${ }^{28}$ ЦДА, ф. 971К, оп. 1, а.е. 31, л. 695-696.

${ }^{29}$ Пак там, л. 951.

${ }^{30}$ Пак там, л. $1017-1018$.

${ }^{31}$ Пак там, а.е. 35 , л. $1099-1100$.

32 Пак там, а.е. 37 , л. $1253-1258$

${ }^{33}$ ЦДА, ф. 791 К, оп. 1 , а.е. 43 , л. 358.

${ }^{34}$ Цанков С. Българската православна църква ... - С. 211.

${ }^{35}$ ЦДА, ф. 791К, оп. 1, а.е. 50, л. 383-384.

${ }^{36}$ Пак там, а.е. 60 , л. 144.

${ }^{37}$ Цанков С. Българската православна църква ... - С. 211.

${ }^{38}$ Пак там. - С. 211-212.

${ }^{39}$ Цанков С. Богословският факултет у нас (1923-1933). - София, 1933; Юбилейно тържество по случай тридесетгодишнината на Духовната академия (Богословския факултет) 1923-1953. - София, 1953.

${ }^{40}$ Цьрковен вестник. - 1927. - № 28. - 16 юли.

${ }^{41}$ ЦДА, ф. 791 К, оп. 1, а.е. 48 , л. $253-254$.

${ }_{42}^{42}$ Цанков С. Българската православна църква ... - С. 322.

${ }^{43}$ ЦДА, ф. 791 К, оп. 1, а.е. 47 , л. 1435. 
${ }^{44}$ Църковен вестник. - 1932. - № 20. - 14 май.

45 Димитров В. История на радиото в България. - Т. 1. - София, 1994. - С. 191.

${ }^{46}$ ЦДА, ф. 791 К, оп. 1, а.е. 55, л. 1456.

${ }^{47}$ Пак там, а.е. 57, л. 212-213.

${ }^{48}$ Пак там, а.е. 59, л. 231-232.

${ }^{49}$ Пак там, а.е. 57, л. 778-779.

${ }^{50}$ Пак там, а.е. 63, л. 286-287.

51 Пак там, л. 431.

52 Църковен вестник. - 1939. - № 3. - 13 ян.; Църковен вестник. - 1939. - № 4. - 20 ян.

${ }^{53}$ Пак там. - 1940. - № 14. - 12 февр.

${ }^{54}$ ЦДА, ф. 791К, оп. 1, а.е. 42, л. 98-99.

${ }^{55}$ Пак там, а.е. 44, л. 819.

${ }^{56}$ Пак там, а.е. 47, л. 957.

${ }^{57}$ Пак там, а.е. 53, л. 296.

${ }^{58}$ Пак там, а.е. 66, л. 87.

${ }^{59}$ Пак там, а.е. 64, л. 85, 95.

${ }^{60}$ Пак там, а.е. 62, л. 367.

${ }^{61}$ ЦДА, ф. 791 К, оп. 1, а.е. 40, л. 432-440.

${ }^{62}$ Пак там, л. 577-578.

${ }^{63}$ Пак там, а.е. 41, л. 792-821.

${ }^{64}$ Стоянова В. Българската православна църква и изпълнителната власт // 120 години изпълнителна власт в България. - София, 1999. - С. 229.

${ }^{65}$ ЦДА, ф. 791 К, оп. 1, а.е. 41, л. 792-821.

${ }^{66}$ Пак там, а.е. 43, л. 669-670.

${ }^{67}$ Пак там, л. 849-850; а.е. 44, л. 1101-1106.

${ }^{68}$ Цанков С. Българската православна църква... - С. 218-219.

${ }^{69}$ Стоянова В. Българската православна църква... - С. 229.

${ }^{70}$ Пак там. - С. 265-270; Тулешков П. История на свещеническия съюз. - София, 1928.

${ }^{71}$ Цанков С. Българската православна църква... - С. 271-279.

${ }^{72}$ Пак там. - С. 279-284.

73 Пак там. - C. 285.

${ }^{74}$ Пак там. - С. 249-253.

${ }^{75}$ Народен страж. - 1938. - № 4. - 1 февр. 